\title{
Appendiceal Carcinoid cM1 TNM Finding v7
}

National Cancer Institute

\section{Source}

National Cancer Institute. Appendiceal Carcinoid CM1 TNM Finding v7. NCI Thesaurus. Code C89940.

Appendiceal carcinoid with distant metastasis. (from AJCC 7th Ed.) 